\title{
THE EUROPEANIZATION OF THIRD COUNTRY JUDICIARIES THROUGH THE APPLICATION OF THE EU ACQUIS: THE CASES OF RUSSIA AND UKRAINE
}

\author{
Roman Petrov* and Paul Kalinichenko**
}

\begin{abstract}
The aim of this article is to look at the phenomenon of Europeanization of judiciaries of third countries through the prism of EU external policy. It is argued that external factors (objectives of EU external policies, EU soft law, EU technical and financial assistance, favourable interpretation of EU law by the ECJ towards third country nationals) play important role in persuading third country judiciaries to apply the EU acquis in their judgments. The similar pattern can be envisaged with regard to Russia and Ukraine. Case study shows that EU policies towards these countries led to generally favourable attitude towards applying the EU acquis by Russian and Ukrainian courts, though mainly as a persuasive source of law. However, problems linked to effectiveness, independence and fight with corruption hinder further Europeanization of judiciaries in Russia and Ukraine.
\end{abstract}

\section{INTRODUCTION}

The term 'Europeanization' is often used as an interdisciplinary and ideological concept, employed in political, historical, economic and, of course, legal environments. However, these contexts do not affect the essence of Europeanization, which is understood as the process by which subjects adopt certain European features. ${ }^{1}$ While accepting that the origins of Europeanization lie in the European continent, and that the term therefore suggests that a subject adopts everything that is truly 'European' (culture, history, politics and law), it must be acknowledged that this notion has

* PhD (London), Jean Monnet Chair in EU Law, National University 'Kyiv-Mohyla Academy' (Ukraine), Alexander von Humboldt Research Fellow at the University of Heidelberg (Germany), Email: petroveulaw@googlemail.com. This article is based on Dr Petrov's talk on the same topic at the University of Oxford on 6 May 2009. The authors would like to thank Dr Adam Ure for his valuable assistance and anonymous reviewers for their insightful comments. Particular thanks to the Alexander von Humboldt Stiftung and Jean Monnet Programme for their support. The usual disclaimer applies.

** $\mathrm{PhD}$ (Moscow), Jean Monnet Lecturer in EU Law, Kutafin Moscow State Academy of Law (Russia), Email: paulkalinichenko@mail.ru.

${ }_{1}$ See further J Olsen, 'The Many Faces of Europeanisation' ARENA Working Papers, 2002, available at <http://www.arena.uio.no > . C Radaelli, 'Europeanisation: Solution or Problem?' (2004) 8 (16) (EIoP, available at <http://www.eiop.or.at $>$. 
expanded beyond its initial boundaries, and is now applied in a variety of cases, for internal and external purposes.

In the internal domain, Europeanization is linked to the influence of the EU dynamic acquis $^{2}$ on the legal orders of EU Member States, and to the need to adapt their institutional and legal structures in accordance with EU requirements. In the external domain, on the one hand, Europeanization can be associated with the growing role of the EU as a global player. ${ }^{3}$ Indeed, the EU has acknowledged this role through its various external policies and initiatives directed towards third countries. For instance, Europeanization was a major ideological motive behind the accession of 10 Central and Eastern European countries into the EU, which were obliged to adopt the EU's expansive 'accession acquis' in order to meet its rigorous membership criteria. On the other hand, Europeanization became a standard label attached to the EU's various external policies directed towards its immediate neighbours, for example the Stabilization and Association Process in the Balkans, the Union for the Mediterranean, the European Neighbourhood Policy (ENP) and Eastern Partnership. ${ }^{4}$ In contrast to enlargement, these policies envisage not full EU membership, but 'integration without membership' by third countries into the EU's political, economic and legal domains, based on the sharing of European common values. In practice, it is always a difficult task for the EU to promote Europeanization in other countries, which either do not want or are unable to join the EU.

This article does not deal with the multi-dimensional and complex phenomenon of Europeanization in its total scope, but endeavours to clarify only one aspect - the Europeanization of the judiciaries of third countries. We believe this essential to ensure the success of Europeanization both in its internal and external dimensions, mainly because neither the EU acquis nor European common values can be promoted abroad without their effective application by judiciaries in the recipient countries. It should be admitted that study of the Europeanization of the judiciary in third countries is an ambitious and complex task. It warrants a sophisticated interdisciplinary approach in

\footnotetext{
${ }^{2}$ Henceforth we apply the notion 'EU acquis' instead of 'EU law' to emphasize the comprehensive and complex nature of the EU legal heritage. See, generally, R Petrov, 'Exporting the acquis communautaire into the legal systems of third countries' (2008) 13 EFAR 33-52.

${ }^{3}$ M Cremona, 'The Union as a Global Actor: Roles, Models and Identity' (2004) 41 CMLR $553-573$.

${ }^{4}$ The ENP was launched in 2004 (Communication from the Commission 'Wider EuropeNeighbourhood: A New Framework for Relations with our Eastern and Southern Neighbours' (COM (2003) 104 final) and covers immediate and close neighbouring countries to the EU (Armenia, Algeria, Azerbaijan, Belarus, Egypt, Georgia, Israel, Jordan, Lebanon, Libya, Moldova, Occupied Palestinian Territory, Syria, Tunisia and Ukraine. Information is available at <http://ec.europa.eu/world/enp/policy_en.htm >, accessed 17 March 2011. The Eastern Partnership was launched in 2009 as a complementary policy to the ENP (Communication from the Commission and the European Parliament to the Council "Eastern Partnership" (COM (2008) $823 \mathrm{final}$ ). It covers former Soviet countries which participate in the ENP (Moldova, Ukraine, Belarus, Armenia, Azerbaijan, and Georgia) with exemption of Russia.
} 
order to embrace not only the legal, but also the socio-legal, historical and cultural aspects of this phenomenon. Otherwise it is very difficult to explain and comprehend why judiciaries in third countries could be inclined to align their legal practices with best European standards. However, due to evident constraints in scope and volume of this article, we cannot aim to achieve this. Instead we focus only on one narrow aspect of the Europeanization of judiciaries, that is, the application of the EU acquis by third countries' judges in their decisions, and we endeavour to discover the reasoning and motivations of third country judiciaries for doing this. For this purpose we shall look for external and internal factors which might encourage third country judiciaries towards a favourable application of the EU acquis. With regard to external factors we shall highlight the influence of EU external policies on the Europeanization of judiciaries in third countries. With regard to internal factors we shall try to clarify whether application of the EU acquis bears a systematic character and what factors are likely to influence this process. In other words we shall try to answer whether EU external policies are successful in promoting EU legal standards outside the EU, and identify what makes third country judiciaries receptive to these influences.

The scope of this study is confined to two countries with long histories of close relations with the EU: Russia and the Ukraine. In our opinion, a comparative analysis of these countries is highly relevant. Both of them share a common historical and legal heritage. Russia and Ukraine are immediate geographical neighbours of the EU and have built up a framework of bilateral relations with the EU on the same contractual basis, ie the Partnership and Cooperation Agreements (PCA). ${ }^{5}$ However, the objectives and nature of Russia's and Ukraine's relations with the EU have changed considerably in the course of the last decade. Russia does not participate in the ENP, and is not willing to join the EU in the foreseeable future. Instead of aspiring to a crosspillar contractual framework with the EU, Russia is eager to develop sectoral cooperation, similar to either EU-US cooperation, or the sectoral partnership between the EU and Switzerland. ${ }^{6}$ In contrast, Ukraine takes an active part in the ENP, and aspires to enhance its contractual relations with the EU with a clear view to EU membership. ${ }^{7}$ However, the EU expresses its well-justified

5 EC-Russia PCA [1997] OJ L327, entered into force 1 December 1997; EC-Ukraine PCA [1998] OJ L49, entered in force 1 March 1998. Both these agreements have expired but were prolonged upon consent of the parties. Negotiations on new enhanced agreements between the EU and Russia and Ukraine are underway. For academic analysis of the PCAs see C Hillion, 'Partnership and Cooperation Agreements between the European Union and the New Independent States of the Ex-Soviet Union' (1998) 3 EFAR 399-420.

6 S Kashkin, P Kalinichenko, "Problema 2007" v otnosheniakh mezhdu Rossiey i Evropeyskim Souzom i pravovye puty ee reshenia' (2005) 3 Zhurnal zarubezhnogo zakonodatelstva i sravnitelnogo pravovedenia 68-87.

7 R Petrov, 'Legal and Political Expectations of Neighbouring Countries from the European Neighborhood Policy' in M Cremona and G Meloni (eds), The European Neighbouhood Policy: A Framework for Modernisation? EUI Law Working Paper, 2007/21, 7-22. 
interest in accelerating the Europeanization of the administrative and judicial institutions in both countries, owing to their strategic geographical positions, and the importance of expanding the EU common market. Therefore, the examples of Russia and Ukraine can help demonstrate whether EU external policies have produced any impact on the Europeanization of the legal systems of these countries.

Our study of the Europeanization of the Russian and Ukrainian judiciaries has several aims. First, we shall consider how the EU's external policies towards Ukraine and Russia deal with the issue of legal reform. In particular, we seek to clarify whether the different objectives of specific EU external policies towards the EU's neighbours (the ENP and the EU-Russia Strategic Partnership) have led to different results in the Europeanization of Russia's and Ukraine's judiciaries. Secondly, we shall offer a historical overview of the application of international and European law by the judiciaries in Russia and Ukraine. At this point we shall analyze if judges in these countries have departed from the Soviet legacy and moved towards a more friendly interpretation of international and European law. Thirdly, we shall look at the application of the PCAs and the relevant EU acquis by domestic and constitutional courts in Russia and Ukraine. This will establish if the PCAs and relevant EU acquis are perceived by judges to be part of their national legal systems. We shall also be able to ascertain whether judges in Russia and Ukraine are willing to interpret national laws in line with best international and European standards.

II. EUROPEAN UNION EXTERNAL POLICIES AND THE EUROPEANIZATION OF THE RUSSIAN AND UKRAINIAN LEGAL SYSTEMS

The ENP was devised as a framework policy to export democracy, stability and security to the EU's neighbours, in order to create a circle of friends around the EU's borders involving countries which will not join the EU in the near future. ${ }^{8}$ Within this triangle the promotion of stability presumes democratization, good governance and the stability of institutions in the neighbouring countries. One of the basic means to achieve these objectives is to ensure the effective functioning of the judiciary as a prerequisite of the correct and efficient application of the rule of law. ${ }^{9}$ Judiciary reforms should be of prime importance for the neighbouring countries which hope to join the EU in the long-term future. The so-called 'fourth accession criteria', adopted at the Madrid European Council in December 1995, emphasize that candidate countries must set up the institutional capacity of their administrative and

8 ibid 4. See also M Cremona and C Hillion, 'L'Union Fait la Force? Potential and Limitations of the European Neighbourhood Policy as an Integrated EU Foreign and Security Policy' EUI LAW Working Paper, 2006/36.

${ }^{9}$ For instance, Recommendation No. 1/2005 of the EU-Ukraine Partnership and Cooperation Council of 21/02/2005 on the implementation of the EU/Ukraine Action Plan. 
judicial institutions to apply and implement the acquis communautaire. At the same time, the ENP does not hide the fact that judicial reform in the neighbouring countries could be of pragmatic benefit for the EU, since the 'strengthening of the functioning of the judicial system will also contribute to a better investment climate' for potential EU investors. ${ }^{10}$ Therefore, the Europeanization of the judiciary in third countries has considerable ideological and practical importance for engaged third countries, as well as for the entire EU. Specific steps to reform the judiciaries in neighbouring countries are identified in the bilateral Action Plans (AP), concluded with almost all countries participating in the ENP and in Association Agendas (AA) (concluded only with Ukraine to date). ${ }^{11}$ For example, the EU-Ukraine AA targets the objective of:

[C]ontinuing reform of the judiciary and of the court system so as to further strengthen the independence, impartiality, and professionalism of the judiciary and courts, notably by enhancing the training of judges, court officials and prosecutors as well as support staff and law enforcement agencies staff. ${ }^{12}$

Further means to strengthen the independence and effectiveness of the judiciary are envisaged in the bilateral Justice and Home Affairs Action Plans, signed by the EU with certain neighbouring countries, including Russia and Ukraine. $^{13}$

Ukraine is one of the key participants and beneficiaries of the ENP. Hitherto, the EU has influenced the Ukrainian judiciary in two different ways. Firstly, the EU regularly monitors and encourages judicial reform in Ukraine by means of soft law documents borrowed from the EU accession process (action plans, country reports). Results of the monitoring reveal the EU's growing concern with the independence, impartiality and efficiency of the Ukrainian judiciary and law enforcement bodies. The EU continuously emphasizes the existence of 'high-level' corruption, including so-called 'political corruption' within the Ukrainian judiciary. The EU believes that the improvement of the business and investment climate in Ukraine is linked to the aim to set up a 'transparent and predictable legal and administrative framework as well as an independent judiciary'. ${ }^{14}$

${ }^{10}$ ibid.

${ }^{11}$ Information available at $<$ http://ec.europa.eu/world/enp/documents_en.htm $>$, accessed 17 March 2011.

${ }^{12}$ EU-Ukraine Association Agenda to prepare and facilitate the implementation of the Association Agreement (substituted the outdated EU-Ukraine AP from 23 November 2009), available at <http://ec.europa.eu/external_relations/ukraine/docs/index_en.htm $>$, accessed 17 March 2011.

${ }_{13}$ For example, EU Action Plan on Justice and Home Affairs in Ukraine [2001] OJ C77/01.

14 Joint Evaluation Report of EU-Ukraine Action Plan, March 2008, available at $<$ http:// ec.europa.eu/external_relations/ukraine/docs/ukraine_eu_joint_evaluation_2008_en.pdf $>$, accessed 17 March 2011. The evidence of the deteriorating state of corruption is the fact that Ukraine dropped from rank 107 (out of 158) in 2005 Transparency International's Perceptions of Corruption Index to rank 134 (out of 178) of the same Index in 2010. 
Secondly, the EU offers considerable financial and technical assistance for the reform of the Ukrainian judiciary in line with EU best standards through the European Neighbourhood Partnership Instrument (ENPI). ${ }^{15}$ In the period 2007-2010 alone, Ukraine obtained 494 million Euros for the implementation of the EU-Ukraine Action Plan, including the strengthening of the independence and effectiveness of the Ukrainian judiciary. ${ }^{16}$ The EU funds projects to enhance the capacities of the Ukrainian judiciary and law enforcement bodies in international cooperation in criminal matters, and to set up European Policy Legal Advice Centre. ${ }^{17}$ The EU, alongside the Council of Europe, launched an ambitious project entitled 'Ukraine-Transparency, Independence, efficiency of the judicial system, and increased access to justice for all citizens' to draft new legislation and to train judges and prosecutors in the application of best EU and Council of Europe legal and judicial practices and case law. ${ }^{18}$ The EU persistently encourages Ukraine to intensify cooperation with the Council of Europe, the Organisation for Security and Cooperation in Europe (OSCE) and other international institutions in combating corruption, for instance, joining the Council of Europe's Group of States against Corruption (GRECO). ${ }^{19}$

The EU's attempts to reform the Ukrainian judiciary have achieved some degree of success. ${ }^{20}$ In 2010 the Ukrainian judiciary underwent a comprehensive structural reform aimed at establishing a system of specialized courts and improving transparency in the course of appointing judges. The Ukrainian court system enjoys better transparency and information support (establishing administrative courts, and the creation of an electronic database holding all national court decisions). The Ukrainian judiciary and law enforcement institutions have entered into active cooperation with EU agencies such as

15 Regulation 1638/2006 of the European Parliament and the Council of 24 October 2006, laying down General Provisions Establishing a European Neighbourhood and Partnership Instrument [2006] OJ L310/1. Article 2.2.(d) of the Regulation that assistance can be offered with objective 'promoting the rule of law and good governance, including strengthening the effectiveness of public administration and the impartiality and effectiveness of the judiciary, and supporting the fight against corruption and fraud'.

16 Available at < http://www.enpi.org.ua/en/enpi/national-programs >, accessed 17 March 2011.

17 This is EU funded think tank comprised European and Ukrainian experts in EU law and economics. It offers expert assistance to the Ukrainian government. More information is available at <http://www.ueplac.kiev.ua >, assessed 17 March 2011.

18 Information about the project is available at $<$ http://www.jp.coe.int/CEAD/JP/Default. asp?TransID=146>, accessed 17 March 2011.

19 Communication from the Commission to the Council and the European Parliament 'On Strengthening the European Neighbourhood Policy. ENP Progress Report. Ukraine' COM (2006) 726 final. The EU stated that 'progress [in Ukraine] is being hindered by endemic corruption, which is the main challenge to the development and economic growth of Ukraine, and by the lack of a truly independent judiciary' (Communication from the Commission to the Council and the European Parliament 'On Strengthening the European Neighbourhood Policy in 2007. ENP Progress Report. Ukraine’ COM (2008) 164).

${ }^{20} \mathrm{See}<\mathrm{http} / / / \mathrm{ec}$. europa.eu/world/enp/pdf/action_plans/ukraine_enp_ap_jls-rev_en.pdf $>$, accessed 17 March 2011. 
EuroJust and FRONTEX. ${ }^{21}$ However, these changes have not altered the reputation of the Ukrainian judiciary as one of the most corrupt institutions in the country. EU experts warn that the Ukrainian judiciary faces serious problems in the quality and substance of the legal training of its judges, as well as their regular professional training and funding. As a result, judicial decisions in Ukraine do not always comply with rule of law standards, and are often made arbitrarily. ${ }^{22}$ Independent surveys show an alarming level of widespread corruption among judges ( 40 per cent of judges admitted having been offered bribes - there are no statistics on judges admitted having been taken bribes in Ukraine and Russia). ${ }^{23}$ As a consequence, the majority of Ukrainians do not have trust in the judicial system, but consider it corrupt, politically biased and non-transparent. ${ }^{24}$

The EU's strategy on judicial cooperation and reform in Russia differs from the strategy towards the Ukraine. Independent surveys on Russia show an alarming level of corruption in the judiciary, similar to that in the Ukraine, and a very low level of public trust in Russian judicial institutions. ${ }^{25}$ However, in contrast to the Ukrainian case, the EU carefully avoids any criticism and public statements on the Russian judiciary, despite growing international concern over its fairness and effectiveness. ${ }^{26}$ This attitude from the EU can be explained partly by the fact that Russia does not participate in the ENP and distances itself from any future plans to join the EU. Instead, EU-Russia relations are based on the EU-Russia Strategic Partnership, which does not envisage the same means of monitoring and conditionality found in the ENP. Therefore, the EU's influence over the Russian judiciary is exercised mainly

21 For instance, on 12 June 2007 the EU and Ukraine signed a working agreement with FRONTEX (the European Border Exchange Agency) which allows better exchange of information and cooperation with courts in the EU.

${ }^{22}$ See 'The Rule of Law in Ukraine, Report by Sir Brian Neill and Sir Henry Brooke' (The Slynn Foundation) from December 2008, available at <http://www.britishukrainiansociety.org/ en/index2.php?option $=$ com_content\&do_pdf $=1 \& \mathrm{id}=171>$, accessed 17 March 2011. In particular, the Report puts forward the idea that arbitrary judicial decisions by Ukrainian judges are explained by lack of guidelines from higher courts and preference to apply procedural law over substantive law in their judgments.

${ }^{23}$ See the regular surveys of Ukrainian judiciary system by the 'Rule of Law Project' funded by the US Agency for International Development, available at < http://www.usaid.gov/locations/ europe_eurasia/countries/ua >, accessed 17 March 2011.

24 ibid. Surveys show that 72.6 per cent Ukrainians have no trust in the judiciary and are aware of its corruption; this figure is rising by 9 per cent annually. Interestingly enough only 55.9 per cent of respondents believe that Ukrainian citizens are law abiding only in the cases, when it is of benefit to them (See Analytical Report 'Corruption and Service Provision in Judicial System in Ukraine’ by Kyiv International Institute of Sociology, 2006).

${ }_{25}$ Transparency International ranks Russia 154 and Ukraine 134 out of 178 positions in its Corruption Perception Index 2010. Available at < http://www.transparency.org/policy_research/ surveys_indices/cpi/2009/cpi_2009_table $>$, accessed 17 March 2011. For comprehensive sociological research in corruption in Russia see A Ledeneva, Russia's Economy of Favours: Blat, Networking and Informal Exchange (CUP, Cambridge, 1999).

${ }^{26}$ For instance, see Global Corruption Report 2007: Corruption in Judicial Systems (CUP, Cambridge, 2007). This study finds that in Russia, an estimated US\$210 million in bribes is thought to be spent on Russian courts annually. 
through judicial cooperation in civil and criminal matters, ${ }^{27}$ and in four common spaces. ${ }^{28}$ Within the common space with Russia on freedom, security and justice, the EU promotes 'common values such as democracy, respect for human rights and fundamental freedoms'. ${ }^{29}$ These values 'must reflect the necessary balance between Security, on the one hand, and Justice and Freedom, on the other'. ${ }^{30}$ The only soft law instrument which may potentially accelerate the Europeanization of the Russian judicial system is the Common Spaces Road Map (Road Map), underpinned by the Common EU Strategy towards Russia in justice and home affairs. ${ }^{31}$ The Road Map aims 'to contribute to the efficiency of the judicial system in EU Member States and Russia, and to the independence of the judiciary, and to develop judicial cooperation between EU and Russia'. For this purpose, the EU and Russia agreed to 'cooperate, including a thorough exchange of experience on judicial reform in order to ensure the independence and the effectiveness of judiciary in the EU Member States and Russia based on the rule of law, organize professional training for contact points, judges, prosecutors and law enforcement officials as appropriate'. ${ }^{32}$ The Road Map envisages regular monitoring of its implementation. However, since the launch of Common Spaces in 2004, the EU Progress Reports have not been tackling the issue of independence of the Russian judiciary at all. Instead, the EU underlined its readiness to support the improvement of effectiveness and access to justice in Russia, and training of judges through EU financial and technical assistance. The newly born EURussia 'Partnership for Modernisation' (launched on 1 June 2010) could significantly contribute to the 'effective functioning of [the Russian] judiciary and strengthening the fight against corruption' by means of regular monitoring

27 EU Strategy towards Russia in the area of justice and home affairs envisages judicial cooperation in civil and criminal matters. In the former case the EU supports twinning on cooperation between Constitutional Courts of Russia and EU Member States, and the creation of administrative courts. In addition, the EU enables Russia to benefit from the Technical Assistance and Information Exchange (TAIEX) Programme, available at $<$ http://ec.europa.eu/enlargement/ taiex/index_en.htm > , accessed 17 March 2011. Also the EU wants to enhance judicial cooperation in civil matters through the framework of the Hague Conference on Private International Law. In the latter case the EU encouraged Russia to sign several Council of Europe legal documents including the Second Additional Protocol to the 1959 European Convention on Mutual Assistance in Criminal Matters and the Convention on Cybercrime, see the Second Progress Report on the implementation of the strategy for the External Dimension of JHA: Global Freedom, Security and Justice 21 May 2008 9391/08, available at < http://www.eurowarrant.net/ documents/cms_eaw_id1821_2_CouncilDoc.9391.08.doc >, accessed 17 March 2011.

28 At the St Petersburg Summit in May 2003, the EU and Russia agreed to reinforce their cooperation by creating in the long term four 'common spaces' in the framework of the EURussia PCA (Common Economic Space, Common Space of Freedom, security and Justice, Common Space of External Security, Common Space of Research and Education).

29 EU-Russia Road Map on Common Space of Freedom, Security and Justice, available at $<$ http://ec.europa.eu/research/iscp/pdf/russia_eu_four_common_spaces-\%20roadmap_en.pdf $>$, accessed 17 March 2011.

30 ibid.

ibid.

32 ibid. 
of EU-Russia dialogue. ${ }^{33}$ However, at this time, it is difficult to predict the effectiveness of the 'Partnership for Modernisation' since this initiative is aimed at the enhancement of bilateral trade and investment. Therefore, it is likely that the Parties will use the 'Partnership for Modernisation' as a quid pro quo instrument in their bilateral relations, including the Europeanization of the Russian judiciary.

Russia benefited from about 2.7 billion Euros of TACIS funds in the period 1991-2006. ${ }^{34}$ A portion of these funds was directed to reform the Russian legal system and judiciary, in particular to ensure a 'truly independent judiciary' to attract European investment, and to enhance the enforcement of contracts by Russian courts. From 2006, financial and technical assistance to Russia has been covered by the ENPI. In fact, Russia is only one example of a non-ENP country which could benefit from the ENPI. The specific ENPI areas of cooperation, in which the EU assists neighbouring countries' judiciaries, are: the promotion of legislative and regulatory approximation towards EU standards; strengthening the neighbouring countries' national institutions and promoting the rule of law and good governance, including improving the effectiveness of public administration and the impartiality and effectiveness of the judiciary; and supporting the fight against corruption and fraud. Assistance under the framework of the ENPI is based on the principle of conditionality. Therefore, at least in theory, EU assistance can be terminated if a recipient's policy infringes the ENPI's basic principles (principles of good neighbourliness, liberty and democracy, human rights, and the rule of law). However, the EU has never applied any substantive sanctions towards Russia, even during the conflict in South Ossetia in $2008,{ }^{35}$ or in the Second Russia-Ukraine gas dispute in 2008-2009. Commentators argue that it is optimistic to believe that the EU Member States could ever reach the majority vote required to apply article 28 of the ENPI Regulation and suspend assistance to Russia. ${ }^{36}$ It is unlikely to happen in the foreseeable future, since '[the ENPI] has the potential to undermine the claims to partnership and joint ownership of EU-Russia relations'. 37

In the years to come, the objective of Europeanizing third countries' judiciaries will attract even more attention from EU institutions. The changes envisaged in the Lisbon Treaty are designed to enhance the coherence of the EU's external actions, and to strengthen the role of the EU as a global player.

33 Joint Statement on the Partnership for Modernisation EU-Russia Summit 31 May-1 June 2010 (Presse 154), available at < http://ec.europa.eu/external_relations/russia/index_en.htm > , accessed 17 March 2011.

34 Available at < http://www.delrus.ec.europa.eu/en/p_259.htm >, accessed 17 March 2011.

35 According to the European Council Conclusion from 1 September 2008 the EU recognized the Russian military action to enforce peace in South Ossetia as disproportional, and postponed the negotiation of the New Partnership Agreement with Russia (CONCL 3, 12594/08).

36 For instance, S Blockmans, 'EU-Russia Relations Through the Prism of the European Neighbourhood and Partnership Instrument' (2008) 13 EFAR 167-187.

37 ibid 187. 
Article 21 TEU amended by the Lisbon Treaty provides that the EU shall seek to develop relations and build partnerships with third countries and international organizations which share universal democratic principles. In the course of its external action, the EU will pursue the task of safeguarding its values, fundamental interests, security, independence and integrity; consolidating and supporting democracy, the rule of law, human rights and the principles of international law, and promoting an international system based on stronger multilateral cooperation and good global governance. These ambitious objectives imply that the EU should not only export the EU acquis and international legal norms into the legal orders of third countries, but should also ensure the effective application and implementation of these norms by the respective judiciaries.

The cases of Russia and Ukraine provide a good illustration of the enhanced bilateralism of EU external policy towards its neighbours. First, different EU external policies have different approaches to the reform of third countries' judiciaries. In the case of Ukraine, the EU is active in monitoring the state of the judiciary and offering technical and financial assistance to reform it. In the case of Russia, the EU prefers not to get involved in the evaluation of the Russian judiciary, but instead to take all possible means to engage it in judicial cooperation in civil and criminal matters. Secondly, neither of these different approaches has produced substantial effects: judiciaries in Ukraine and Russia are recognized by the international community as ineffective and corrupt, and as not performing to international and European standards. Below, we shall examine whether EU external policies have effectively influenced and encouraged Russian and Ukrainian judges to apply international and EU law in their decisions.

\section{THE IMPACT OF THE EU ON THE EUROPEANIZATION OF THE RUSSIAN JUDICIARY}

Having outlined the content and nature of judicial cooperation between the EU on the one hand and Russia and Ukraine on the other, we now turn our attention to specific issues of the Europeanization of judiciaries in these States. Our first case study is the Europeanization of the Russian judiciary. For this purpose we shall endeavour to clarify several issues. First, to what extent are Russian judges receptive to the application of the EU acquis in their judgments? Second, what factors encourage Russian judges to do so? Finally, is there a link between the application of the EU acquis by Russian courts and EU external policies towards Russia?

With regard to the first question, one can state that there are very few historic and legal prerequisites for the application of the EU acquis by the Russian judiciary. This could be explained by the absence of any formal legal grounds for the application of the EU acquis in the Russian legal system. Indeed, Russia had never considered itself bound by any legal acts of the EU, since there are no international legal acts which impose any kind of 
commitment on Russia to abide by EU law. The only legal possibility for Russian judges is to apply the EU acquis as part of international public law. However, the Russian judiciary has historically been unenthusiastic towards the application of international law sources. Most judges and law academics in post-Soviet countries gained their legal education and practical experience in the USSR. Therefore, in post-Soviet countries, very little experience in applying international law in judgments has been passed on to contemporary judiciaries. This is because cases in which Soviet courts applied international agreements were exceptionally rare. ${ }^{38}$ Even in these rare cases, the application of international agreements by Soviet courts was of a strictly limited nature. The directives of the ruling Communist Party, not universal principles of international law, constituted the foundation of the Soviet legal system regarding the application of international law in the USSR, and these directives therefore provided the guidelines for Soviet courts. ${ }^{39}$ The objective of the Soviet theory of international law was to preserve the concept of 'sovereignty', in order to protect the country's own system of socialistic government and the supremacy of Soviet law, and in particular, the supremacy of the fundamental principles of the socialist State (nationalization of property without compensation, wars against colonialism, no protection of private property). Even during perestroika, the formal theory of international law in the USSR stated that no international treaty could automatically alter Soviet municipal law. International agreements could be considered as self-executing if their provisions either fully corresponded to existing national municipal law, or regulated previously unregulated relations. International human rights conventions could not have priority over national law, owing to their vagueness and generality, and therefore could not be directly applied by Soviet courts. The primacy of international law over national law as a matter of principle was not recognized. ${ }^{40}$ The official Soviet doctrine of the application of international law explicitly stated that the Soviet Constitution of 1977 'possessed prior legal power upon the territory of the country and had priority over the international obligations of the country'. ${ }^{41}$

The collapse of the entire Communist bloc in 1989 and the consequent dissolution of the USSR led to comprehensive political and constitutional

38 S Marochkin, 'International Law in the Courts of the Russian Federation: Practice of Application’ (2007) 6 Chinese Journal of International Law 329-344.

39 A Drucker, 'Soviet Views on Private International Law' (1955) 4 ICLQ 884-889.

40 J Hazard, 'Soviet Yearbook on International Law 1987' (1990) 84 AJIL 303-305. See also FJM Feldbrugge, Encyclopedia of Soviet Law (Oceana Publications, Leiden, 1973).

41 V Kartashkin, Prava cheloveka $v$ mezhdunarodnom $i$ vnutrenem prave (Moscow, 1995) 16; N Blatova (ed), Mezhdunarodnoe Publichnoe Pravo (Moscow, 1987) 64. In accordance with the Soviet theory of relations between international public law and municipal law application and the enforcement of international agreements concluded by the USSR in the Soviet legal system could take place only in cases when: a) provision of an international agreement is applied together with relevant provision of Soviet legislation; b) priority application of provision of international agreement over relevant provision of Soviet law. 
reforms in the new post-Soviet countries. Most post-Soviet states adopted new constitutions in which the relationship between international law and municipal law in the constitutional orders of these countries was substantially revised. This revision had the objective of showing the international community the greater openness of these countries to the outside world, and adherence of international legal best practices.

The adoption of the new Constitution of the Russian Federation in 1993 gave Russian courts better possibilities to directly apply international law and universal principles of international law than in Soviet times. In accordance with article 15(4) of the Russian Constitution:

Universally recognized principles and norms of international law as well as international agreements of the Russian Federation should be an integral part of its legal system. If an international agreement of the Russian Federation establishes rules, which differ from those stipulated by law, then the rules of the international agreement shall be applied. ${ }^{42}$

Henceforth, formal reasons to abstain from the application of international law disappeared, and therefore the Russian courts became more inclined to apply provisions of international agreements in their decisions, albeit not on a regular and consistent basis. It is worth noting that at the time of its adoption, the Russian Constitution had the most liberal provision regarding the application of international law within a national legal system among all former Soviet countries. Consequently, the provisions of the Russian Constitution on application of international law gave greater opportunities for Russian judges to apply and interpret international law in accordance with their constitutional acts than their Ukrainian colleagues or any other judges from the former USSR. As commentators acknowledge, "international law is not longer "alien" for [Russian] courts. They widely refer to it and apply it as well as domestic norms'. ${ }^{43}$ This could be explained by several reasons of a legal nature. Firstly, according to article 15 of the Russian Constitution, which lays down the fundamentals of the constitutional system in Russia, the application of international norms and principles within the Russian legal order is irrevocable from the supremacy of the principle of rule of law in the Russian Constitution. ${ }^{44}$ Secondly, self-executing international agreements ratified by the State Duma (the Russian parliament) enjoy primacy and direct effect within the Russian legal order. ${ }^{45}$ Thirdly, the application of international law by domestic courts in Russia is favourably influenced by resolutions

\footnotetext{
42 The full text in English is available at $<$ http://www.kremlin.ru/eng/articles/ConstMain. shtml >, accessed 17 March 2011.

${ }^{44}$ E Kozlova and O Kutafin, Konstitutsionnoe Pravo Rossii (Moscow, 1995) 101.

45 Federal Law 'On International Treaties of Russian Federation' Law of 15 July 1995, 101FZ, Sobranie Zakonodatelstva Rosiyskoy Federatsii, 1995, No. 29, 2757. In particular, article 5(3) of this law states: 'The provisions of the officially published international agreements of the Russian Federation are directly applicable in the Russian Federation, if they do not require the adoption of domestic acts for their application'.
} 
(explanations) of the Russian High Courts (Constitutional Court, Supreme Court, High Commercial Court-unlike in Ukraine there is no system of administrative courts in Russia). These resolutions do not form a formal case-law finding for lower Russian domestic courts, but do constitute a source for the interpretation of primary and secondary Russian law for them. ${ }^{46}$ However, the application of international law by the Russian judiciary has not been completely smooth. There are cases when Russian judges openly ignore or even reject the application of international law in their judgements. ${ }^{47}$

The major incentive for Russian judges to apply the EU acquis stems from the EU-Russia Partnership and Cooperation Agreement (PCA). Since 1997 the EU-Russia PCA has been the key legal document regulating EU-Russia relations. This agreement lays down the foundation of contractual relations and forms a departure point for the Europeanization of the Russian legal system. The EU-Russia PCA occupies a unique place in Russian law as its first multi-pillar framework international agreement with conditionality clauses. The partnership envisaged in the EU-Russia PCA is not declarative, but foresees concrete bilateral political and economic cooperation between the parties. The legal basis of the EU-Russia partnership expands beyond traditional boundaries of international law. For the very first time in Soviet or Russian history, Russia's bilateral relations with one of the largest political and economic blocks in the world focus not only on inter-state relations, but also on establishing a better environment for Russian nationals and providing access to the EU internal market. For the very first time in history, Russian nationals and subjects are real beneficiaries and addressees of legal rights, permissions and prohibitions in the EU-Russia PCA.

The Russian judiciary treats the EU-Russia PCA as an international agreement which contains self-executing rules within the Russian legal order. In case of conflict, Russian judges prefer to acknowledge the priority of the EU-Russia PCA over national legislation. ${ }^{48}$ This makes the EU-Russia PCA an efficient instrument for bilateral cooperation without its further implementation into the Russian legal system. Russian courts consider the EURussia PCA an international agreement which guarantees the protection of rights and interests of Russian nationals and subjects in their economic relations with the EU. ${ }^{49}$ Hitherto, Russian courts developed considerable experience in applying provisions of the EU-Russia PCA in their decisions, though mainly in economic related fields (trade, customs and tax). There is a quite limited practice of Russian courts related to democratic and human

46 R Livshitz, Precedent kak Istochnik Prava (Moscow, 1997) 4.

47 See 'Protiv ignorirovaniya praktiki EvroSuda', available at < http://www.golosa.info/ node/1122 > , accessed 17 March 2011.

${ }_{48}$ More than 20 cases on applying the PCA and about 100 cases with links to the EU law are known in the Russian judicial practice today.

49 P Kalinichenko, 'Primenenie Soglashenia o Partnerstve i Sotrudnichestve mezhdu Rossiey i EC Rossiskimi sudami’ (2007) 11 Zakon 225-234. 
rights clauses in the EU-Russia PCA which mainly deals with EU-Russia economic relations. In general, the Russian judiciary has acknowledged the importance of the principle of the respect of democratic principles and human rights for the partnership between Russia and the EU as enshrined in article 2 of the EU-Russia PCA. Respect of human rights, fundamental freedoms and the rule of law are interpreted by Russian courts as principles corresponding to the provisions of the Russian Constitution. Russian courts confirmed that these principles are of a legal nature and form common values shared by the EU, its Member States and Russia. For instance, in the British Bankv the Svyatoslav Fyodorov 'Eye Microsurgery' clinic case, ${ }^{50}$ the Russian Supreme Court considered that article 98 of the PCA could form the legal ground for the execution of judgment by a British court in Russia. In the notorious YUKOS case ${ }^{51}$ the Federal Commercial Court of Russia acknowledged that the duty of Russian courts to recognize foreign judicial decisions, which can serve as the legal basis for the execution of judgment of any national court of EU Member State (article 98 of the EU-Russia PCA), follows from the general objectives of the EU-Russia PCA governing sincere cooperation between the parties to the agreement (article 2 of the EU-Russia PCA).

Analysis of case law of the Russian courts shows that, undoubtedly, the EU-Russia PCA found better reception by Russian courts in economic related fields. For instance, despite not being bound by WTO law, Russian courts recognized the possibility of the application of selected GATT/GATS rules mentioned in the EU-Russia PCA. ${ }^{52}$ Russian courts applied the EU-Russia PCA with the purpose of protecting the rights of European investors who exercised the freedom of establishment within the territory of Russia, on the basis of the most-favoured nation treatment in accordance with provisions of articles 28 and 30 of the EU-Russia PCA. In the Volvo Car Corporation $v$ Patent Dispute Chamber and 'Verit' v Patent Dispute Chamber cases the Federal Commercial Court of Moscow District confirmed that the EU-Russia PCA imposes binding commitments on Russia with regards to the protection of intellectual property rights, and therefore relevant provisions of the EURussia PCA have priority over relevant national legislation. ${ }^{53}$ Furthermore, Russian courts frequently referred in their decisions to the EU-Russia sectoral

50 Judgment of the Supreme Court of Russia of 7 June 2002 (5-Г02-64).

51 Judgment of the Federal Commercial Court of Moscow District of 2 March 2006 (KG-A40/ 698-06-P).

52 For instance, Judgment of the Federal Commercial Court of North-West District of Russia of 8 October 1998, Master Shipping v Tax Office of St.-Petersburg (A56-11044/98), Judgment of the Federal Commercial Court of Moscow District of 7 April 1999 'Popelensky and Partners' $v$ Central Bank of Russia (KA-A40/824-99 BPP), Judgment of the Federal Commercial Court of Far East District of Russia of 24 September 2001 Sakhalinmorneftegas $v$ Office for Monetary Control of Sakhalin Region (F03-A59/01-2/1791).

53 See Judgment of the Federal Commercial Court of Moscow District of 29 June 2005 (KA-A40/5565-05) and Judgment of the Federal Commercial Court of Moscow District of 31 August 2005 (KA-A40/8111-05). 
agreements in science and technology, the export of certain steel products, and in tax cases.

In the opinion of some Russian judges, the binding and self-executing character of the EU-Russia PCA provides legal ground for the application of EU primary and secondary legislation in their judgments. ${ }^{54}$ Of course, Russian courts never acknowledged that they should apply EU primary law or the principles of EU law in their decisions. However, in the Nalchinsky Zavod Poluprovodnikovykh Priborov v Custom Office of Kabardino-Balkaria case, the Federal Commercial Court of North-Caucasus District of Russia confirmed at appeal level that Russia is not bound by the EC Treaty but, at the same time, did not exclude the possibility of applying provisions of the EC Treaty if it follows from the objectives of the EU-Russia PCA. ${ }^{55}$

Nevertheless, it would be premature to state that Russian courts consistently and systematically apply EU secondary law in their judgements. EU secondary law has been cited by Russian courts on several sporadic occasions. In some cases, these references were based on article 55 of the EU-Russia PCA, which contains the soft obligation of Russia to approximate its legislation in a specific field to that of the EU. This happened only in cases where Russian federal laws give preference to Russia's international obligations over its national legislation. ${ }^{56}$ In other cases, references to EU secondary legislation were justified by mutual commitments to ensure equal treatment of Russian and EU nationals provided in the EU-Russia PCA. Furthermore, on rare occasions Russian courts referred to the case law of the European Court of Justice (ECJ). For instance, the Commercial Court of the City of Moscow referred to ECJ case law in interpreting the EC Sixth Tax Directive in relation to the rights of the taxpayers regarding VAT. ${ }^{57}$

Looking at the pattern of application of the EU acquis by Russian courts more widely, we can make several observations. The first observation is that Russian judges do not apply the EU acquis as a separate source of law, but consider it as part of international public law. Russian judges are fully aware that EU law is not binding in the Russian legal system, and therefore refer to EU legal sources exclusively through the prism of the EU-Russia PCA. However, in some cases, EU primary and secondary law have found application in judgments of Russian courts not as a binding but as a persuasive source of law. ${ }^{58}$

54 Judgment of the Federal Commercial Court of North Caucasus District of Russia of 2 July 2003 Nalchinsky Zavod Poluprovodnikovykh Priborov v Custom Office of Kabardino-Balkaria (F08-1873/2003-839A).

55 ibid para 16 and 17.

56 Art 4(4) of Russian Federal Law 'On technical regulations', adopted on 18 December 2002.

57 Joint Cases C-354/03, C-355/03 and C-484/03 Optigen Ltd., Fulcrum Electronics Ltd., Bond House Systems Ltd v Commissioners of Customs \& Excise [2006] ECR 483; Case C-384/04 Federation of Technological Industries v Commissioners of Customs \& Excise [2006] ECR 4191.

${ }_{58}$ Order of the Constitutional Court of the Russian Federation of 19 February 2009 (137-O-O) (case Beslan mothers); Judgment of the Constitutional Court of the Russian Federation of 22 June 2010 (14-P) (case Malitsky); Order of the High Court of the Russian Federation of 31 July 2008 
In the course of studying the phenomenon of the Europeanization of the third country judiciary we should move beyond the simple description of the application of EU law by Russian courts. It is important to speculate what makes, or could make, Russian judges positive about referring to the EU acquis in their judgments. Is it a consequence of either external or internal influences or both? We suggest that the resort to the favourable application of the EU acquis by Russian judges amounts to both external and internal impacts. The former stems from the EU's willingness to integrate Russia into European political, economic and legal spaces (Common Spaces Initiative, Justice and Home Affairs Action Plan). Closer engagement of Russian judges with European judicial cooperation encourages a better reception of EU law in their judgements. Furthermore, the issue of reciprocity may play a very important role in EU-Russia judicial cooperation. Favourable interpretation of the EU-Russian PCA by the ECJ indirectly encourages the Russian judiciary towards a reciprocal treatment of agents in Russia in line with international and EU law standards. For instance, the Simutenkov case ${ }^{59}$ illustrated that Russian nationals can protect their rights provided by the EU-Russia PCA in EU domestic courts. This possibility of protecting the rights and legal interests of Russian nationals through EU law and the better access of Russian nationals to the EU internal market was welcomed by scholars and lawyers in the EU and Russia. ${ }^{60}$ Recently, the equal treatment of Russian subjects in the EU internal market was confirmed by the judgment of the General Court (then the Court of the First Instance) of 11 September 2008 in the JSC KirovoChepetsky Khimichesky Kombinat v Council case, ${ }^{61}$ where a Russian company obtained the annulment of the Council regulation imposing a definitive antidumping duty on imports of new types of the products, including ammonium nitrate, without undertaking appropriate antidumping investigations. In the meantime, the General Court is considering similar actions by Russian companies, ${ }^{62}$ as well as actions brought by companies from Ukraine, ${ }^{63}$ and Kazakhstan. ${ }^{64}$ Recognition of some provisions of the EU-Russia PCA as directly effective in the EU legal order, and, consequently, the equal treatment

(KAS08-434) (case NPO “Rezonans"); Judgment of the Federal Commercial Court of Moscow District of 15 April 2009 (A40-31562/08-130-338) (case Natsrybkachestvo).

59 Case C-265/03 Igor Simutenkov v. Ministerio de Educación y Cultura, Real Federación Española de Fútbol [2005] ECR I-2579.

60 For example, P Kalinichenko, 'Zashita prav grazhdan Rossii v EC v contexte dela Simutenkov' (2008) 11 Zakon, 211-220. Case note by C Hillion, 'Case C-265/03 Simutenkov v Ministerio de Educación y Cultura, Real Federación Española de Fútbol [2005] ECR I-2579' (2008) 45 CMLR, 815-833.

${ }^{61}$ Case T-348/05 JSC Kirovo Chepetsky Khimichesky Kombinat v Council [2008] ECR II-00159.

62 Case T-84/07 Mineral and Chemical Company EuroChem v Council (OJ 2007 C117/26).

63 Case T-249/06 Niko Tube and Nyzhniodniprovskyi Tube Plant v Council [2009] ECR II-00383.

64 Case T-192/08 Tansnational Company Kazchrome and ENRC Marketing $v$ Council (OJ 2008 C197/26). 
of Russian nationals and subjects in the EU, considerably encourages the willingness of Russian courts to apply similarly favourable treatment towards European nationals and companies. ${ }^{65}$

Another important external factor for the Europeanization of the Russian judiciary is case-law of the European Court on Human Rights (ECtHR), which provides a greater impact on the Europeanization of the Russian legal system than the EU-Russia PCA. This is because, in accordance with article 15(4) of the Russian Constitution, the European Convention of Human Rights (ECHR) is an integral part of the Russian legal order and a formal source of the Russian legal system and enjoys priority over Russian federal laws. The ECtHR is considered by Russian society one of the most respectable and authoritative judicial institutions because judgments of the ECtHR proved to be important practical guarantees for protecting fundamental rights and freedoms of Russian nationals. ${ }^{66}$ The application of the ECHR and other conventions of the Council of Europe has become a customary practice of the Russian Constitutional Court. ${ }^{67}$ This approach is shared by the Russian Constitutional Court and other Russian domestic courts. Russian courts refer to conventions of the Council of Europe and the ECtHR case law mainly in civil, commercial and criminal cases. ${ }^{68}$ Moreover, Russian judicial practice shows that the implementation of the ECHR on its own, without reference to the ECtHR case law, can lead to the incorrect implication of the former. ${ }^{69}$ Russian High Courts have emphasized the need to implement the ECHR into the Russian legal system in line with ECtHR case law. In some cases, Russian courts have applied EU law and ECHR simultaneously. For instance, in the YUKOS case the possibility of the enforcement of the foreign judicial decision in Russia was justified not only by article 98 of the EU-Russia PCA, but also by article 6 of the ECHR and relevant ECtHR case law. ${ }^{70}$

With regard to the impact of internal factors on the Europeanization of the Russian judiciary several aspects could be relevant. First, the application of the EU acquis by Russian courts reflects the increasing popularization of EU

${ }^{65}$ P Kalinichenko, 'Zashita prav grazhdan Rossii in EC v contexte dela Simutenkov' (2008) 11 Zakon 211-220.

${ }^{66}$ There is a growing number of claims against Russia from Russian nationals to the ECtHR. Hitherto the ECtHR has considered 1079 cases wherein the Russian government was a respondent. In 815 cases the Russian government was found in violation of the ECHR. As of 31 December 201040295 cases are pending their further consideration by the EctHR against Russia: see Annual Report 2010 of the ECtHR, available at <http://www.echr.coe.int/ECHR/EN/ Header/Reports + and + Statistics/Reports/Annual + Reports $>$.

${ }^{67}$ M Salikov, 'Aspects of protection of Citizens of the Russian Federation in the European Court of Human Rights' (2006) Uppsala Yearbook of East European Law 98-115, at 106.

${ }^{68} \mathrm{G}$ Danilenko, 'Implementation of International Law in CIS States: Theory and Practice' (1999)10 EJIL 51-69, at 68.

${ }^{69}$ A Burkov, 'Implementation of the Convention for the Protection of Human Rights and Fundamental Freedoms in Russian Courts' (2006) 1 Russian Law: Theory and Practice 71.

70 Judgment of the Federal Commercial Court of Moscow District of 2 March 2006 (KG-A40/ 698-06-P). Hornsby v Greece, ECHR (1997), ECHR Rep, 1997-II, 510, 40. 
law among the Russian legal elite. Thanks to financial and technical assistance from the EU and other international organizations, courses related to EU law are being introduced to recent and future judges at leading law higher education institutions in Russia and regular judicial workshops are conducted. ${ }^{71}$ Eventually, these measures bore fruit and encouraged agents of change within the Russian judiciary to be more open towards the application of EU law in their judgments. These agents consider application of the EU acquis in their judgments a very good opportunity to indicate their positive attitude towards Europeanization. However, these rather sporadic cases are not sufficient to overturn a general skeptical attitude towards the application of EU law among Russian judges. One could argue that application of the EU acquis by Russian courts is rather an exception than the rule.

The second internal factor is the increasing transparency of the Russian judiciary. Traditionally, the Soviet and Russian judiciary was not positive towards the public access to their own judgments by a wider audience. Selected cases were published in few authorized judicial periodicals (eg Herald of Russian Supreme Court). Today, the Russian judiciary is developing a single case law database of Russian courts which is called to contribute to the better transparency and academic study of such case law. Undoubtedly, the transparency and monitoring of Russian case law indirectly encourages agents of change within the Russian judiciary towards a better perception and application of best international and European legal standards in their judgments.

Nevertheless, one should be aware of major constrains on the Russian judiciary's road to Europeanization. The major constrain for applying the EU acquis is a lack of consistent experience in applying EU law, as well as Council of Europe law. This is because Russian judges are often ill-informed about the substantive and procedural means of the correct application of international law in cases that conflict with national law. Not all Russian judges have an accurate understanding of the ECJ and ECtHR case law. Sometimes, the application of EU law before Russian courts is an example of blunt mistakes and a lack of awareness of the fundamentals of EU law by either party. ${ }^{72}$

\footnotetext{
71 Such as TAIEX. See: Council Decision of 23 January 2006 enabling countries covered by the European Neighbourhood Policy, as well as Russia, to benefit from the Technical Assistance and Information Exchange (TAIEX) Programme (OJ 2006 L32/80). For instance compulsory EU law related subjects were introduced to curricula of the Kutafin Moscow State Academy of Law, the Moscow State Institute of International Relations (University), and the Peoples' Friendship University of Russia. Due to financial and technical support from the EU the European Studies Institute was set up at the Moscow State Institute of International Relations in 2006. This institution as well as the Kutafin Moscow State Academy of Law bear major burden in educating Russian civil servants in area of EU law.

${ }^{72}$ For instance, in the Lobachev case (Judgment of the High Court of Russia of 21 October 2008, GKPI08-1741), Russian prisoner Vyacheslav Lobachev asked the High Court of Russia to apply article 47 of the EU Charter of Fundamental Rights (right to an effective remedy and to a fair trial) as well as provisions of the European Convention of Human Rights. The High Court of Russia refused to consider the EU Charter of Fundamental Rights as relevant source of law due to
} 
Consequently, they are not willing to undertake the additional responsibility of applying the provisions of EU and international law in their judgments. Unfortunately, this gap is difficult to fill in by conservative nature of judicial pleadings in Russian courts (as well as in courts of other former Soviet countries). In practice, parties to judicial procedure are discouraged to refer to international and European legal sources because of Russian judges' preference of applying formal Soviet-born methods of legal interpretation in their judgments. Modern Russian legal theory devotes very little attention to European-style methods of legal interpretation, such as the teleological method of interpretation which has not found any widespread application. ${ }^{73}$

\section{THE IMPACT OF THE EU ON THE EUROPEANIZATION OF THE UKRAINIAN JUDICIARY}

Ukraine is our second case study. We shall apply the same pattern in looking at the Europeanization of the Ukrainian judiciary. First, we shall look at the extent to which Ukrainian judges are favourable towards the application of the EU acquis in their judgements. Second, what factors encourage Ukrainian judges to do so? Finally, is there any link between the application of the EU acquis by Ukrainian courts and EU external policies towards the Ukraine?

With regard to the first question, it should be emphasized that as the third largest and one of the most industrially developed Soviet republics, Ukraine has always occupied a special place among its Soviet counterparts. After World War II, Ukraine was granted limited competence to participate in international relations through diplomatic representation in international organizations and conferences. For instance, the Ukrainian Soviet Socialist Republic (its official name before 1991) was one of the founding members of the United Nations, a member of UNESCO, and was a party, along with the USSR, to basic international conventions. However, this did not imply that the legal system of the Soviet Ukraine differed from that of the USSR. Soviet Ukraine's legal doctrine unquestionably shared the Soviet concept of the relationship of international law to municipal law. ${ }^{74}$ After gaining independence in 1991, and the adoption of the Constitution of Ukraine in 1996, Ukrainian courts acquired more flexibility in applying international law in their decisions. Article 9 of the Ukrainian Constitution of 1996 provides that:

International treaties that are in force, agreed to be binding by the Verkhovna Rada [Ukrainian Parliament] of Ukraine, are part of the national legislation of Ukraine. The conclusion of international treaties that contravene the Constitution

the fact that Russia has no full membership in the EU and, therefore, based its judgment on the European Convention of Human Rights ((2009) 11 Vestnik Verkhovnogo Suda Rossii).

73 S Shevchuk, 'Tvorcha Rol Syddi u Processi Tlumachenia Konstitusii' (2008) 4 Vystnyk Konstitutsiynogo Sydy Ukrainy 100-109.

${ }^{74}$ For instance, see the works of the former Soviet/Ukrainian judge of the ICJ Koretskiy, Izbrannie trydy (ed Denisov) (Kiev, Naukova Dumka 1989). 
of Ukraine is possible only after introducing relevant amendments to the Constitution of Ukraine. ${ }^{75}$

The Ukrainian Constitution replicates the relevant provision of the Russian Constitution with regard to the binding effect of international agreements within the national legal order, but deliberately excludes internationallyrecognized principles of international law as binding in the Ukrainian legal system. Therefore, it can be argued that, from a formal point of view, the Ukrainian Constitution was drafted as less receptive to the influence of international law than the Constitution of Russia. However, this gap is consistently rectified by the Europeanization of the Ukrainian legal system, and of the Ukrainian judiciary in particular.

The Europeanization of the Ukrainian legal system started shortly after independence in 1991. As a priority, Ukraine set as its political objectives integration into international political and economic structures and, consequently, membership of the Council of Europe and the European Union. Once the Council of Europe set the criteria for membership, the first attempts were made to ensure the conformity of legislation in the spheres of democracy and human rights. As a consequence, Ukrainian criminal, penal and social legislation underwent substantial changes, such as the abolition of the death penalty and the adoption of new criminal, criminal procedural and civil procedural codes. These reforms marked the first steps in the reception of European legal standards into the developing Ukrainian legal system.

Yet the Ukrainian judiciary is criticized for the reluctant application and implementation of international agreements into its own legal system. ${ }^{76}$ Ukrainian courts refer mainly to international agreements which are duly signed and ratified by the Ukrainian Parliament (Verkhovna Rada) and which are self-executing within the Ukrainian legal system. Even in these cases, the correct application of international agreements is not guaranteed, since one of the most important impediments for the application of international law by the Ukrainian judiciary is the correct understanding of these international conventions by national judges. International and European organizations realize this problem and target their assistance towards eliminating the incorrect application of international and European law by Ukrainian

\footnotetext{
75 Full text in English is available at <http://www.rada.gov.ua/const/conengl.htm >, accessed 17 March 2011.

76 This happens mainly due to: 1) the belief that international case law is not relevant to civil law systems; 2) luck of translation of international case law and jurisprudence into Ukrainian to help judges to adapt their decisions to best European standards. Furthermore, the Verkhovna Rada of Ukraine is not always expedient in solving conflicts between ratified international agreements and national legislation. See D Wilkinson, "Interpreting Ukrainian legislation in light of international law and jurisprudence", available at < http://www.ukma.kiev.ua/ua/nauka/pratsi_vidan/ nz/index.php?option=com_content\&task=view\&id=52\&Itemid=31>, accessed 17 March 2011. Also see G Burd, 'High Commercial Court tramples international agreements', available at < http://www.kyivpost.com/opinion/op_ed/28483 >, accessed 17 March 2011.
} 
judges. ${ }^{77}$ This has led to the rise of judicial activism among Ukrainian judges in the 'post-Orange Revolution' period, such as in the Yuschchenko case, ${ }^{78}$ where the Ukrainian Supreme Court opened a door for Ukrainian courts to apply the judgments of other international tribunals and courts. ${ }^{79}$

The Constitutional Court of Ukraine can be regarded as the largest recipient of international and European technical and expert assistance. ${ }^{80}$ Subsequently, it has proved to be an undisputed champion among other Ukrainian courts in referring to international law and universally-recognized principles in its own decisions. In most cases, these references relate the protection of constitutional rights and freedoms: the freedom of association, the right to participate in public management, the right to vote and to be elected, the right to a fair trial, and others. The Constitutional Court of Ukraine justifies references to international legal documents by the fact that Ukraine's ratification of fundamental international and regional conventions (in particular the ECHR) permitted Ukrainian citizens, foreigners and stateless persons to refer to international bodies to protect their rights in cases where they are not adequately protected by the judiciary in Ukraine. In the majority of judgments the Constitutional Court of Ukraine endeavoured to interpret the provisions of the Ukrainian Constitution in line with best international and European legal standards. ${ }^{81}$ However, there is still no uniformity among Ukrainian constitutional judges on the boundaries of applying international law and ECHR law in their decisions. Some judges believe that Ukrainian courts should apply ECtHR case law in line with national characteristics in order to preserve national constitutional values. ${ }^{82}$ Other judges favour more frequent and

77 Good example of such assistance is jointly funded by the EU and Council of Europe project "Transparency and efficiency of the Judicial System of Ukraine" with budget of 6 million Euro conducted in the period from 2008 to 2011. One of the major objectives of this project was to improve "Efficiency of the judicial system strengthened and quality of judicial decisions corresponding to European standards". For more information see $<$ http://www.coe.int/t/dghl/ cooperation/capacitybuilding/projects/tejsu_en.asp >, accessed 17 March 2011.

78 Decision of Supreme Court of Ukraine on 3 December 2004 Yuschenko $v$ Central Election Committee of Ukraine.

79 N Prescott, 'Orange Revolution in Red, White, and Blue: US Impact on the 2004 Ukrainian Election’ (2006) 16 Duke J of Comp \& Int Law 219-248.

80 Judges of the Constitutional Court of Ukraine are regular visitors to international tribunals, European constitutional courts, participants to international and European professional and academic events. The Constitutional Court of Ukraine pursues active cooperation with the Council of Europe, EU, Venice Commission and other international institutions. See further <http:// www.ccu.gov.ua/en/index $>$.

${ }^{81}$ M Selivon, 'Harmonistsia natsionalnogo zakonodavstva z normami mizhnarodnogo prava i yogo vykorystannia Konstitutsiynym Sudom Ukraini’ (2003) 3 Vystnyk Konstitutsiynogo Sydy Ukrainy 36-51.

${ }^{82}$ Decision 23/2001 of the Constitutional Court of Ukraine on 15 June 2001 (Bank Savings case). See V Temchenko, 'Vydnosyny mizh praktikoy ECtHR i jurisprudentsii Konstitutsiynogo Sydy Ukrainy' (2007) 4 Vystnyk Konstitutsiynogo Sydy Ukrainy 91-99. On the same problem encountered in the post accession period by constitutional courts in Central and Eastern Europe see A Albi, 'Ironies in Human Rights Protection in the EU: Pre-Accession Conditionality and Post-Accession Conundrums' (2009)15 ELJ 1, 46-69. 
effective references to international law, and to ECHR and EU law, in order to ensure a more effective protection of the constitutional freedoms of Ukrainian nationals. Furthermore, some Constitutional Court judges advocate the necessity of applying more elements of the EU acquis in their decisions, due to Ukraine's pro-European policies and its aspirations for EU membership. ${ }^{83}$ In the end, it cannot be ruled out that Ukrainian constitutional judges in the near future might change their preferences in line with the level and nature of political relations between the Ukraine and international and European organizations (the EU in particular).

In most decisions taken by the Constitutional Court of Ukraine, the EU acquis is applied as a persuasive source of law. For instance, in the course of comparative analysis the Constitutional Court referred to EC Regulation 2004/2003 'on the regulations governing political parties at European level and the rules regarding their funding, ${ }^{84}$ along with the ECHR and ECtHR case law in its ruling on the constitutionality of the Ukrainian law 'On political parties in Ukraine ${ }^{85}$ Furthermore, the Constitution Court of Ukraine referred to EC Council Directive $2000 / 78^{86}$ in its ruling on the constitutionality of Ukrainian laws 'On public service', 'Diplomatic service', and 'Local self governmental service ${ }^{87}$ It is remarkable that in both cases the Constitutional Court did not offer any reasoning as to why it decided to refer to these particular sources of the EU acquis.

One of the central questions of this study relates to factors which encourage Ukrainian judges to apply the EU acquis in their judgments. Is there any link between the application of the EU acquis by Ukrainian courts and EU external policies towards Ukraine? We believe that external factors like advanced political and economic cooperation and strong conditionality in relations between the EU and Ukraine play an important role in the Europeanization of the Ukrainian judiciary.

The Ukrainian decision to embark on a new political trajectory, aimed at rapprochement with the $\mathrm{EU}$, was proclaimed in 1994 with the signing of a Partnership and Cooperation Agreement (PCA) with the EU and its Member States. By signing and subsequently ratifying the PCA, Ukraine accepted its soft commitment to 'endeavour to ensure [emphasis added] that its legislation be gradually made compatible with that of the Community'. In response to the ambiguous 'approximation clause' in the PCA, the Ukraine designed the

${ }^{83}$ V Kampo, 'Konstitutsionalisatsiya zovnishnoi politiki Ukraini: Eurointegratsionnie aspecty’ (2007) 6 Vystnyk Konstitutsiynogo Sydy Ukrainy 50-61.

84 Regulation 2004/2003 of the European Parliament and the Council of November 42003 'On the regulations governing political parties at European level and the rules regarding their funding' [2003] OJ L297.

85 Decision of the Constitutional Court of Ukraine on 12 June 2007, No. 2/2007.

86 EC Council Directive 2000/78 of 27 November 2000 establishing a general framework for equal treatment in employment and occupation [2000] OJ L303/16.

87 Decision of the Constitutional Court of Ukraine on 16 October 2007, No. 8/2007 (case on the maximum retirement age for civil servants). 
notion of the 'adaptation' of national law to EU legislation. For the time being, this notion is unique to the Ukraine since it satisfies at least the PCA's soft approximation commitment and ensures that the EU pays attention to the Ukraine's European aspirations. Furthermore, the adaptation of Ukrainian laws to EU legislation provides some hope that the EU might offer a new model of mutual relations which could potentially bring the Ukraine into an enlarged Europe. ${ }^{88}$ In fact, soft approximation commitments in the EUUkraine PCA are of considerable legal value for the Ukrainian judiciary. This can be explained by external and internal factors. Externally, the Ukrainian judiciary acknowledges the Ukraine's active engagement into the ENP and Eastern Partnership, ${ }^{89}$ which both require it to align its legislation with EU law. Internally, the Ukrainian judiciary takes into account national legislation on the gradual approximation of national legislation to the EU acquis. For instance, the Ukrainian law 'On the All State Programme on the adaptation

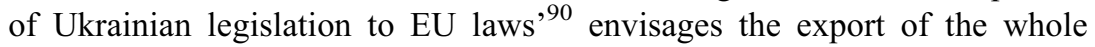
'accession acquis' into Ukraine's legal system, since the objective of this law is the 'alignment of the Ukrainian legislation with the acquis communautaire, taking into consideration criteria specified by the EU towards countries willing to join the EU'. In other words, Ukraine readily agreed to implement the 'accession acquis' on a voluntary basis, without any prospect of full EU membership. It should be noted that the EU never indicated that voluntary harmonization would lead to the immediate recognition of Ukraine's desire to join the EU. Nevertheless, in many official documents and public statements the Ukrainian government considers the voluntary harmonization of national legislation to EU law and gradual adoption of the EU acquis as an essential factor in accelerating Ukraine's integration into the EU.

External factors which encourage the Ukrainian judges to apply the EU acquis imply various internal factors of a socio-legal nature. In contrast to the reception of the EU-Russia PCA by Russian judges, the EU-Ukraine PCA is perceived by some national judges as not only a binding international agreement, but as something more essential for the Ukrainian legal system. Some Ukrainian judges believe that the voluntary application of the EU acquis is a key prerequisite for democratic transformation of the Ukrainian society, in line with best international and European practices. In the event of a conflict

88 R Petrov, 'Recent Developments in the Adaptation of Ukrainian Legislation to EU Law' (2003) 8 EFAR 125-141. V Muraviov, 'Pytannia harmonisatsii vnutrishnogo prava neassociovannykh krain z pravom Evropeyskogo Souzy’ (2003) 4 Pidpriemnitsvo, hospodarstvo ta pravo 91-94.

${ }^{89}$ This initiative was proposed by Poland and Sweden in 2008 as complimentary to the ENP with the objective of enhancing the political, economic and legal integration of Eastern neighbouring countries (Ukraine, Belarus, Moldova, Georgia, Armenia and Azerbaijan). The Eastern Partnership Programme was formally launched on 20 March 2009. See < http://ec.europa.eu/ external_relations $>$

90 Law of the Verkhovna Rada of Ukraine 'About the All State Programme of adaptation of Ukrainian legislation to that of the EU', 18 March 2004, No. 1629-IV. 
between PCA provisions and national law, Ukrainian courts recognize the primacy and direct effect of the latter. For example, in the Ryvne Customs Office $v$ Demyanyk case, ${ }^{91}$ the High Commercial Court of Ukraine acknowledged the direct effect and supremacy of article 15 of PCA over conflicting national legislation regarding the regime of the treatment of EU companies in Ukraine. Beyond that, some Ukrainian courts justify their references to EU law by the 'soft' approximation clauses in article 51 of the EU-Ukraine PCA. For instance, in the Chernomortechflot v Odessa Tax Office case, ${ }^{92}$ the High Commercial Court of Ukraine referred to the freedom of transit provided in the PCA, and to the 'approximation clause' of the EU-Ukraine PCA (article 51), as a justification for following the EC's definition of an 'international transport corridor'. The importance of Ukraine's soft approximation commitments and their far-reaching consequences for the legal system of Ukraine was emphasized by the District Administrative Court of Kiev in the Person $v$ State Agency in nationalities and religions case. ${ }^{93}$ There the Kiev District Administrative Court referred to the Ukrainian law 'All State Programme on the adaptation of Ukrainian legislation to EU law', and stated that the aim of adapting Ukrainian legislation requires the alignment of Ukrainian legislation to the acquis communautaire, which covers EU primary and secondary law, and to ECJ case law. For this purpose, the judgment of the Kiev District Administrative Court among other relevant sources of law mentions EC Directive $2004 / 83^{94}$ which is 'frequently applied by the European Court on Human Rights' as a relevant guideline for the court.

Specific target oriented EU financial and technical assistance to Ukraine is another important factor in the Europeanization of the Ukrainian judiciary. The newly-born Ukrainian administrative judiciary, established through the active technical and expert support of international and European organizations (Council of Europe, OSCE, EU), ${ }^{95}$ proved to be another champion of the application of the EU acquis in Ukrainian courts. The idea behind administrative court reform in Ukraine was to increase the accountability of governmental bodies in line with best European principles, as achieved in Central and Eastern European countries which established administrative judiciaries

91 Judgment of the High Commercial Court of Ukraine on 2 February 2005, No. 12/267. Also Judgment of the High Commercial Court of Ukraine on 25 March 2005 (Closed Stock Company 'Chumak' v Kherson Custom Office), No. 7/299. Also Judgment of the High Commercial Court of Ukraine on 22 February 2005 ('Odek' LTD v Ryvne Custom Office) No. 18/303.

92 Judgment of the High Commercial Court of Ukraine on 22 June 2004, No. 28/296-03-6901.

93 Judgment of the District Administrative Court of Kiev on 22 May 2008, No. 4/48. Judgment of the District Administrative Court of Kiev on 13 October 2008, No. 4/375.

94 Council Directive 2004/83 of 29 April 2004 'On minimum standards for the qualification and status of third country nationals or stateless persons as refugees or a persons who otherwise need international protection and the content of the protection granted' [2004] OJ L304.

95 The OSCE conducted about 25 workshops for about 600 judges of administrative courts in Ukraine during the period 2005-2008, funded exchange visits and provided training: see < http:// www.osce.org/item/35850.html >. 
in order to qualify for EU membership. ${ }^{96}$ It encouraged the newly-established Ukrainian administrative courts to import the general principles of EU law and to find inspiration from ECJ and ECtHR case law in cases concerning State liability before individuals. In general, Ukrainian administrative courts justify the application of ECJ case law by the need to follow ECtHR case law. For example, in the Tsesarenko $v$ Representative office of the Pension Fund in Shevchenko district of Kiev case, ${ }^{97}$ the Administrative Court of the Kiev District stated that the principle of the rule of law must be applied in line with ECtHR case law. ${ }^{98}$ The Administrative Court of the Kiev District argued that the implementation of the best European standards of human rights protection in Ukraine will decrease the number of claims by Ukrainian nationals to the ECtHR against Ukraine. ${ }^{99}$

In cases related to State liability before the individual, Ukrainian administrative courts have developed the concept, previously unknown to the Ukrainian legal system, of legal certainty. For example, in the Person v Kiev City Centre for Social Assistance case, ${ }^{100}$ the Administrative Court of the Kiev District imported the principle of legal certainty from ECJ case law. There the Administrative Court of the Kiev District provided that the rights of the disabled to claim social and financial assistance from the State flow from the principle of legal certainty. It means that a State cannot justify its failure to guarantee constitutional rights by the absence of a specific national law. For this purpose, the Administrative Court of the Kiev District referred to the ECJ judgment in the van Duyn $v$ the Home Office case, ${ }^{101}$ wherein it is specified that nationals may rely on the State's obligations, even in cases when these obligations are provided in law without direct effect. Furthermore, Ukrainian courts developed the principle of legitimate expectations in the case of Person $v$ Darnitsa District of Kiev Center for Social Assistance, ${ }^{102}$ concerning the rights to benefits of those who took part in the operation during the Chernobyl

\footnotetext{
96 F Emmert, 'Administrative and Court Reform in Central and Eastern Europe' (2003) 9 ELJ $3288-315$.

97 Judgment of the District Administrative Court of Kiev on 18 November 2008, No. 9/556.

98 Law of Ukraine 'About application of decision of the European Court of Human Rights', adopted on 23 February 2006, No. 3477-IV.

99 Ukraine is in third position after Russia and Turkey with regard to number of claims to the ECtHR. Hitherto there were 982 admissible claims from Ukrainian nationals against the Ukrainian state to the ECtHR. In 602 cases the Ukrainian government was found in violation of the ECHR. As of 31 December 201010434 cases are pending their further consideration by the EctHR against Ukraine: see Annual Report 2010 of the ECtHR, available at <http:// www.echr.coe.int/ECHR/EN/Header/Reports + and + Statistics/Reports/Annual + Reports $>$.

100 Judgment of the District Administrative Court of Kiev on 26 June 2008, No. 4/337. Apparently, this judgment became pattern for subsequent decisions by Ukrainian administrative judges (See judgments of the District Administrative Court of Kiev (on 10 November 2008, No. 5/435, on 24 November 2008, No. 5/503, on 25 November 2008, No. 2/416, on 1 December 2008, No. 5/451, and many other judgments)).

101 Case 41/74 van Duyn v Home Office ECR 19741337.

102 Judgment of the District Administrative Court of Kiev on 26 June 2008, No. 4/337.
} 
catastrophe. The Kiev District Administrative Court provided that the principle of State liability to offer compensation to those involved in the Chernobyl disaster flows from the van Duyn v Home Office case. In particular, the Administrative Court of the Kiev District stated that if the State formally acknowledged its commitment to offer compensation to those involved in the Chernobyl disaster, it could not refer to its own failure to fulfil its commitments in order to avoid liability, which would also violate the legitimate expectations of Ukrainian nationals.

Notwithstanding the positive trends in the Europeanization of the Ukrainian judiciary one should be aware of the problems of the effective application of the EU acquis in Ukraine. Similar to the Russian case, the majority of Ukrainian judges remain often ill-informed about the substantive and procedural means of the correct application of international law in cases that conflict national law. Not all Ukrainian judges possess a correct understanding of the ECJ and ECtHR case law. However, these difficulties can be gradually solved as long as the result-oriented EU technical and expert assistance continues flowing to Ukraine.

\section{TWO STRATEGIES OF THE RUSSIAN AND UKRAINIAN JUDICIARIES ON THE ROAD}

\section{TO EUROPEANIZATION}

The cases of Russia and Ukraine provide a good illustration of the enhanced bilateralism of EU external policy towards its neighbours. Different EU external policies have different approaches to reforming third country judiciaries. In the case of Ukraine, the EU is active in monitoring the state of the judiciary and offering technical and financial assistance in reforming it. In the case of Russia, the EU prefers not to get involved in the evaluation of the Russian judiciary, but instead takes all possible measures to engage it in judicial cooperation in civil and criminal matters. In spite of generally favourable attitude towards applying the EU acquis by Russian and Ukrainian courts as persuasive source of law these approaches produced very little effects linked to effectiveness, independence and fight with corruption. The judiciaries in Ukraine and Russia are recognized by the international community as ineffective and corrupt, and as failing to perform to international and European standards.

Comparing the application of the EU acquis by Russian and Ukrainian courts one can emphasize several differences. The first is that in contrast to Russia, Ukrainian judges are inclined to apply the EU acquis not only as part of international public law, but as something more substantive. Both the Russian and Ukrainian Constitutional Courts make reference to the EU acquis in their judgments. However, the Russian judiciary refers to the EU acquis only in the context of the EU-Russia PCA, or as a matter of comparative analysis. Unlike in Ukraine, the Russian judiciary does not consider itself bound by any approximation of law commitments arising from the EU-Russia 
PCA. Therefore, the application of the EU acquis by Russian judges takes place on a purely voluntary basis as a persuasive source of law, and its application does not differ from the application of any other source of international public law.

Ukrainian judges have moved beyond the mere mechanic application of the EU-Ukraine PCA as part of international public law applicable to that country. Instead, they experiment with the adaptation of various principles of EU law, such as legal certainty and State liability. Of course, this practice does not imply that the application of the EU acquis by Ukrainian judges takes place in a coherent and systematic way. On the contrary, one can state that the application of the EU acquis bears a non-systematic and sporadic character, as in Russia. Similar to the Russian scenario Ukrainian judges apply provisions of secondary EU law only as a persuasive source of law.

If we consider the external and internal factors which encourage Russian and Ukrainian judges to be positive about referring to the EU acquis in their judgements we could draw further differences between them. The first difference is that the political environment in relations between the EU on one side and Russia and Ukraine on other side is not similar. The pragmatic nature of bilateral EU-Russia relations implies a quite reserved reception of the EU acquis by the Russian judiciary. The Ukrainian case is opposite. Ukraine's pro-European foreign policy is underpinned by the national programme of approximating Ukrainian legislation to EU law. This is a very important encouragement for Ukrainian judges to apply the EU acquis in their decisions. The second difference is the fact that the EU offers better and more result-oriented, technical and financial support to the Ukrainian judiciary than to their Russian counterparts. This support has already caused serious internal institutional reforms within the Ukrainian judiciary, such as the establishment of the system of administrative courts. As the case law of Ukrainian administrative courts shows, administrative judges are inclined to pioneer the application of the EU acquis within the Ukrainian judiciary. Another important internal impact is the better transparency of the Ukrainian judiciary than in Russia. The national registry of Ukrainian case law was launched and found positive feedback among judges and lawyers in Ukraine. Judges and lawyers are regularly informed about developments in EU law via workshops and courses at Ukrainian legal higher education institutions. However, similar to their Russian colleagues, Ukrainian judges still lack consistent experience in applying EU law. Not all Ukrainian judges possess a correct understanding of the ECJ and ECtHR case-law. Consequently, they are not willing to undertake the additional responsibility of applying the provisions of EU and international law in their judgments. Sometimes, the application of EU law before Russian and Ukrainian courts contains examples of obvious mistakes and a lack of awareness of the fundamentals of EU law. 
Carried to its logical conclusion, it can be said that Europeanization is not the only concept that characterizes the process of transitional reforms in third countries. Europeanization, as well as the concepts of 'integration without membership' and 'transformation', ${ }^{103}$ implies that third countries can eventually join a legal space attached to the EU that actually reaches beyond EU borders. It can be acknowledged that an EU legal space is based on the ' 3 Es' principle (effectiveness, efficiency and enforcement) not only in the EU but also in partner countries. ${ }^{104}$ The ability of the judiciary in third countries to ensure the effectiveness, efficiency and enforcement of the EU legal space is crucial. The cases of Russia and the Ukraine provide a good illustration of the EU's considerable impact on the Europeanization of legal systems in neighbouring countries. The EU prefers to achieve this objective mainly through contractual and policy means. In the former case, it implies a particular framework of contractual relations between the EU and third countries. In the cases of Russia and the Ukraine, the EU relied on the PCA as an important contractual foundation for the initial Europeanization of the judiciaries in post-Soviet countries. The examples of Russia and the Ukraine show that national judiciaries acknowledge the significant role of the PCAs in their legal orders, and apply this in binding self-executing international agreements.

In the latter case, the EU pursues different strategies in line with different policy objectives in its relations with Russia and Ukraine in order to Europeanize their judiciaries. In the case of Russia, the EU tries to reform and influence the judiciary by engaging it in better cooperation with civil and criminal matters, and by funding the training of judges and other judicial projects. The EU does not publicly recognize the existence of corruption in the Russian judiciary, but encourages Russia to fight it. The level of monitoring through the EU-Russia Road Map is not effective and mainly declarative. However, despite such limited influence, the Russian judiciary has become more open to the influence of international and European law than in Soviet times. Some Russian judges have become more inclined to refer to various sources of EU law in their judgments, when this could be justified by the objectives of the EU-Russia PCA. It is important to recognize that ECJ case law in the Simutenkov and Kombinat cases encouraged Russian courts to apply the EU-Russia PCA and EU law in their decisions as a matter of reciprocity. Therefore, it could be argued that EU-Russia economic interdependency, and not the EU's political influence on Russia, serves as a major precondition for the Europeanization of the Russian judiciary.

\footnotetext{
${ }^{103}$ For instance, F Maiani, 'Legal Europeanisation as Legal Transformation: Some insights from Swiss “outer Europe”' EUI Working Paper MWP 2008/32, 16-17.

104 A Łazowski, 'Enhanced Multilateralism and Enhanced Bilateralism: Integration without Membership in the European Union’ (2008) 45 CMLR 6 1433-1458.
} 
In the case of Ukraine, the impact of the EU's political influence and its soft power is more evident. Since Ukraine is the key addressee of the ENP, the EU is straightforward in emphasizing the insufficient level of judicial protection and access to justice in Ukraine. The EU applies various soft law tools (action plans, association agenda, country reports) to monitor the pace of judicial reform in Ukraine. Furthermore, judiciary reform is one of the priorities of EU financial and technical support for Ukraine. As a direct consequence of the EU's financial and technical assistance, some Ukrainian judges have become inclined to refer not only to ECJ judgments, but also to import certain principles of EU law into their judgments. As a result, the principle of legal certainty is widely applied by administrative courts in Ukraine. The Constitutional Court of Ukraine refers to EU law in its own decisions in interpreting the Ukrainian Constitution. It creates a solid foundation for aligning the Ukrainian legal system with the EU acquis.

These observations bring us to one important question. What are the most appropriate models of the EU's 'enhanced multilateralism' and 'enhanced bilateralism' in ensuring the success of the ' 3 Es' principle in the EU legal space in Russia and Ukraine? This question is particularly important today, because both Russia and Ukraine are about to enter into new contractual relations with the EU. New enhanced agreements with Russia and Ukraine will replace expired and outdated PCAs. At the same time, these agreements will serve as a model of contractual relations between the EU and other neighbouring countries in the near future. Can, for example, either European Economic Area (EEA) or EU-Swiss bilateral relations serve as a suitable blueprint? In our opinion, it is premature to apply the models of the EEA and of EU-Swiss bilateral relations to the cases of Russia and the Ukraine. Both of these models require a considerable degree of the Europeanization of national judiciaries to ensure the success of the ' 3 E's' in their national legal orders. In the cases of Russia and Ukraine, the EU has not been able to Europeanize their judiciaries and realize true integration, as was achieved with the EEA and Switzerland. The judiciaries of Russia and the Ukraine must overcome and rebuild the negative images they have of political bias and corruption. Homogeneity of the legal systems of both Russia and the Ukraine with the EU has not yet been achieved, because the Russian and Ukrainian judiciaries are not yet acquainted with European methods of teleological interpretation. Furthermore, it could be argued that the immediate application of homogeneity in Russia and the Ukraine could cause problems in bringing about the ' 3 E's' in their national legal systems. However, if the EU succeeds in Europeanizing these two countries' judiciaries, it will definitely result in the realization of an EU legal space, from the East Atlantic coast to the Ural Mountains and beyond. 